\title{
The Climate Change and Rwandan Coffee Sector
}

\author{
Fidele Hakorimana, Handan Akcaoz*
}

Department of Agricultural Economics, Faculty of Agriculture, Akdeniz University, 07070 Antalya, Turkey

\begin{tabular}{l}
\hline A R T I C L E I N F O \\
Review Article \\
Received 16 June 2017 \\
Accepted 17 August 2017
\end{tabular}

Keywords:

Climate

Rwandan coffee

Sustainability

Agricultural systems

Risk

*Corresponding Author:

E-mail: hvurus@akdeniz.edu.tr

\begin{abstract}
A B S T R A C T
This paper provides a detailed overview of the current situation of the coffee sector in the Rwandan economy and identifies the possible challenges that the sector is currently facing. The study has identified the economic and the livelihood indicators for farmers who are engaged in coffee production and also gives the Rwandan coffee sector' situation and its position in the global coffee market. Also, the research has found out that in Rwanda, nearly 500,000 farmers produce coffee along with other crops, notably beans, savory banana and corn and found out that in 2012, coffee accounted for almost 30 percent of Rwanda's total export revenue. On the other hand, the study revealed that the sector throughout all the coffee production process, has undergone different challenges especially climate change as it is reported by the Ministry of Agriculture and Animal resources. A low yield was reported in 2007 and climate variability was quoted among the causes. Insufficient rainfall in the last three months of 2006 (the period of coffee flowering) proceeding the short dry season in the first two months of 2007 was recorded. The reduced rainfall was also poorly distributed across coffee growing regions in Rwanda. In addition, the research revealed that even though the area under coffee production is increasing, the coffee production is decreasing due to unexpected climate change and variability in current years and also the improper use of chemical fertilizers by coffee farmers is very critical. The study concluded that adding value to the coffee supply chain of Rwanda is adding direct economic benefits and important indirect social benefits to the lives of individuals and to the health of communities in Rwanda. Moreover, more effort should continue to raise the profile of the Rwandan coffee sector suggesting that proper use of chemical fertilizers, solid marketing channels and climate change adaptations measures would be the fair ways of making the sector more profitable and considering national targets to increase coffee export revenues, a few simple measures to improve the performance of the sector could have substantial effects on the country's economic growth.
\end{abstract}

DOI: https://doi.org/10.24925/turjaf.v5i10.1206-1215.1376

\section{Introduction}

Rwanda is a landlocked country in Central East Africa with both mountainous terrain and plateaus. It is made up with numerous lakes and elevated at $800-4500 \mathrm{~m}$ above sea level, the country is also known as 'country with a thousand hills', due to its dramatic undulating landscape (WHO, 2015). Rwanda has a total area of $26,338 \mathrm{~km}^{2}$. In 2012, a total resident population of Rwanda was 10,515,973 inhabitants (NISR, 2014) and an estimated population density of 395 per square kilo meter. According to the GoR, 2013, Rwanda is the most densely populated country in Africa and land holdings average less than 0.5 hectare denser than Japan. Even if we include arable land on hillsides, $60 \%$ of farmers own farmland no larger than 0.5 ha. Around 500,000 farmers produce coffee along with other crops, notably beans, savory banana and corn. The average number of trees per farmer varies from 150 to 300 , depending on the region, qualifying the production system as one of micro rather than smallholder. There are, however, a handful of large coffee plantations, the biggest being 53 hectares (USAID, 2007).

Agriculture is the main driver of Rwanda's economic development and poverty reduction, contributing 34\% to GDP and about $90 \%$ to employment of the Rwandan population (GoR, 2011; Boudreaux, 2011). It supplies $90 \%$ of the nation's food and nutritional needs (Rwirahira, 2010). Rwandan agricultural policies and strategies focus on intensification and increased market orientation of the smallholder agricultural sector, and cooperatives are seen as an important vehicle to achieve this (GoR, 2011). The transformation of agriculture therefore will have the greatest impact on the economy in terms of poverty reduction and wealth creation in the country and will continue to remain so for the foreseeable future. 
Agricultural production in Rwanda can be grouped into two main categories: staple crops (leguminous, cereals, roots, tubers and banana) and cash crops (coffee, tea, and pyrethrum). Since agricultural production in Rwanda depends almost exclusively on the quality of the rainy season and specific temperature ranges, it makes the country particularly vulnerable to climate variability and change. The increased frequency and duration of droughts, floods, landslides and erosion currently observed considerably decrease the country's food availability. Moreover, the changing patterns of precipitation and the extreme events of storms and droughts lead not only to a decline in land productivity but also to an increase of plant disease incidences in the study area (GoR, 2011).

The spatial pattern of the agricultural regions and their respective crop growth is determined by the physical environment in Rwanda. The country is characterized by dramatic contrasts in temperature and rainfall as the elevation changes from the lowland savannah areas of the east to the mountain chains of the west. The Rwandan agricultural economy depends on its climatic conditions to a high degree and is thus vulnerable to any changes of weather patterns. The agriculture sector generally is pressured by climate change in the way that periodic floods and droughts (extreme events) already cause major socioeconomic impacts and reduce economic growth in the country. After the 1994 genocide, major flood events occurred in 1997/98, 2006, 2007, 2008, and 2009, where rainfall resulted in infrastructure damage, fatalities and injuries, landslides, loss and damage to agricultural crops, soil erosion and environmental degradation. In some regions of the country there have also been periodic droughts, for example in 1999/2000 and 2005/6 (Ngabitsinze et al., 2011).

In Rwanda, like in much of the developing world, small-scale subsistence farmers produce most of the agricultural output. Agricultural exports represent over $70 \%$ of the total value of exports; coffee and tea are the two main export crops and the most widely cultivated cash crops. The Government of Rwanda has also made efforts to diversify the country's exports by investing heavily in horticulture geared towards exports. The country produces several products as staple foods: maize, sorghum, rice, wheat, beans, soya beans, Irish potato, sweet potato, cassava and bananas (Bizimana et al., 2012).

The aim of this paper was to give a detailed overview of the current situation of the coffee sector in the global economy. This paper provided the information about Rwandan coffee sector, sector organization, production and marketing channels from the producer through the farm gate to the final consumers. The study has identified the economic and the livelihood indicators for farmers who are engaged in coffee production and also has identified the Rwandan coffee sector' situation and its position in the global coffee market.

\section{Overview of Coffee Production in Africa}

Coffee is cultivated in more than 80 countries in Central and South America, Africa and Asia, and ranks among the world's most valuable agricultural commodities. Coffee cultivation provides livelihoods for 20-25 million farming families (ED \&F MAN, 2013). And engages over 100 million people in its producing and processing. Smallholder coffee farmers, together with their families and rural workers produce over $70 \%$ of this labour intensive crop. Women comprise half the productive workforce and play a crucial role that often goes unnoticed. However, to retain the involvement of rural youth is a challenge as they often aspire to a different future and seek employment outside the coffee sector (Panhuysen and Pierrot, 2014).

Coffee producers in Africa accounted for about $12 \%$ of global supply and less than $11 \%$ of global exports of the product for the 2009/10 season. These contributions to the global coffee market are almost equal to Indonesia's, the third largest world producer of the commodity. Notwithstanding the small contribution of African countries to the global coffee market, the commodity constitutes a large proportion of both GDP and exports share in some of the continent's small economies. For example, in Ethiopia and Rwanda, coffee exports generated about $26 \%$ and $22 \%$, respectively, in export revenue in 2009. Particularly notable, coffee production is predominantly produced by small scale farmers who contribute more than 95\% of total production in Ethiopia. Therefore global coffee market conditions have important implications for growth and poverty reduction in the country (AfDB, 2010).

World coffee consumption is growing steadily at around $2.5 \%$ per year, and the demand for coffee is on the rise. Growth is fastest in the emerging markets, such as those in Eastern Europe and Asia, and in the coffee producing countries themselves. The demand is expected to reach 165 million bags in 2020 and calls for around $15 \%$ increase in green bean production over the next 5 years (Panhuysen and Pierrot, 2014).The Table 1 shows the average coffee production in the major coffee producing countries of Africa in the period of 44 years.

Coffee beans are produced in tropical countries located between the Tropics of Cancer and Capricorn, a region known as the Coffee Belt, and are consumed by developed countries in the North. While Brazil, the largest producer takes up one third of the world's production and Vietnam takes up 15, the two countries are producing half of world production of coffee beans. Africa makes up for no more than 10 of the world production, falling behind the coffee production expansion in Latin America and Asia. The key African producers include: Ethiopia, the biggest bean-producing country in Africa where Arabica coffee originates from; followed by Uganda and Côte d'Ivoire. Rwanda ranks the $11^{\text {st }}$ in Africa (Table 2) (ICC, 2015). 
Table 1 Average coffee production in Africa (1970-2014)*

\begin{tabular}{l|ccccc|ccccc}
\hline \multirow{2}{*}{ Country } & \multicolumn{9}{c|}{ Production amount } & \multicolumn{4}{c}{$\%$} \\
\cline { 2 - 10 } & $1970 \mathrm{~s}$ & $1980 \mathrm{~s}$ & $1990 \mathrm{~s}$ & $2000 \mathrm{~s}$ & $2013 / 14^{*}$ & $1970 \mathrm{~s}$ & $1980 \mathrm{~s}$ & $1990 \mathrm{~s}$ & $2000 \mathrm{~s}$ & $2013 / 14$ \\
\hline Côte d'Ivoire & 4155 & 4338 & 3448 & 2692 & 2100 & 21.17 & 21.81 & 21.45 & 17.5 & 12.90 \\
Ethiopia & 2982 & 3128 & 2973 & 4904 & 6600 & 15.19 & 15.73 & 18.49 & 31.88 & 40.55 \\
Uganda & 2692 & 2724 & 2811 & 2924 & 3600 & 13.71 & 13.7 & 17.48 & 19.01 & 22.12 \\
Angola & 2199 & 278 & 65 & 33 & 35 & 11.2 & 1.39 & 0.40 & 0.21 & 0.22 \\
Cameroon & 1462 & 1771 & 1022 & 834 & 315 & 7.45 & 8.90 & 6.36 & 5.42 & 1.93 \\
D.R.C & 1306 & 1610 & 1019 & 383 & 350 & 6.65 & 8.09 & 6.34 & 2.49 & 2.15 \\
Kenya & 1286 & 1726 & 1377 & 766 & 750 & 6.55 & 8.68 & 8.56 & 4.98 & 4.60 \\
Madagascar & 1103 & 1092 & 780 & 490 & 571 & 5.62 & 5.49 & 4.85 & 3.18 & 3.51 \\
Tanzania & 856 & 875 & 779 & 793 & 799 & 4.36 & 4.4 & 4.84 & 5.15 & 4.90 \\
Rwanda & 376 & 583 & 347 & 314 & 246 & 1.92 & 2.93 & 2.16 & 2.04 & 1.52 \\
Burundi & 373 & 526 & 476 & 312 & 161 & 1.9 & 2.65 & 2.96 & 2.02 & 0.99 \\
\hline
\end{tabular}

Table 2 Productivity of coffee farm in Africa (from 2010/11 to 2013/14)*

\begin{tabular}{|c|c|c|c|c|c|c|c|}
\hline Countries & $\begin{array}{c}\text { Average production } \\
(60 \mathrm{~kg} \text {-bags })\end{array}$ & $\%$ & MT & $\%$ & $\begin{array}{l}\text { Acreage } \\
\text { (ha) }\end{array}$ & $\%$ & $\begin{array}{c}\text { Yield } \\
\text { (kg/ha) }\end{array}$ \\
\hline Total Africa & 16143 & 100.00 & 968573 & 100.00 & 2370184 & 100.00 & 408.65 \\
\hline Ethiopia & 6783 & 42.02 & 406977 & 42.02 & 509000 & 21.48 & 800 \\
\hline Uganda & 3330 & 20.63 & 199771 & 20.63 & 282284 & 11.91 & 708 \\
\hline Côte d'Ivoire & 1753 & 10.86 & 105206 & 10.86 & 360000 & 15.19 & 292 \\
\hline Tanzania & 825 & 5.11 & 49484 & 5.11 & 229000 & 9.66 & 216 \\
\hline Kenya & 756 & 4.68 & 45355 & 4.68 & 110000 & 4.64 & 412 \\
\hline Madagascar & 556 & 3.44 & 33367 & 3.44 & 150000 & 6.33 & 222 \\
\hline Cameroon & 440 & 2.73 & 26372 & 2.72 & 120000 & 5.06 & 220 \\
\hline Guinea & 374 & 2.32 & 22469 & 2.32 & 4000 & 0.17 & 488 \\
\hline D.R.C & 336 & 2.08 & 20186 & 2.08 & 200000 & 8.44 & 101 \\
\hline Burundi & 281 & 1.74 & 16864 & 1.74 & 60000 & 2.53 & 281 \\
\hline Rwanda & 270 & 1.67 & 16181 & 1.67 & 42000 & 1.77 & 385 \\
\hline Togo & 125 & 0.77 & 7506 & 0.77 & 40000 & 1.69 & 188 \\
\hline C.A.R & 65 & 0.40 & 3921 & 0.40 & 38000 & 1.60 & 103 \\
\hline Sierra Leone & 61 & 0.38 & 3679 & 0.38 & 15000 & 0.63 & 245 \\
\hline Ghana & 58 & 0.36 & 3497 & 0.36 & 15000 & 0.63 & 233 \\
\hline Nigeria & 43 & 0.27 & 2575 & 0.27 & 50000 & 2.11 & 51 \\
\hline Angola & 33 & 0.20 & 1971 & 0.20 & 52200 & 2.20 & 38 \\
\hline Malawi & 22 & 0.14 & 1292 & 0.13 & 7000 & 0.30 & 185 \\
\hline Liberia & 10 & 0.06 & 612 & 0.06 & 2000 & 0.08 & 306 \\
\hline Zambia & 10 & 0.06 & 576 & 0.06 & 9000 & 0.38 & 64 \\
\hline Zimbabwe & 8 & 0.05 & 498 & 0.05 & 8000 & 0.34 & 62 \\
\hline D.R.C & 3 & 0.02 & 180 & 0.02 & 8000 & 0.34 & 23 \\
\hline Gabon & 1 & 0.01 & 35 & 0.00 & 1500 & 0.06 & 24 \\
\hline Benin & 0 & 0.00 & 0 & 0.00 & 15000 & 0.63 & 0.00 \\
\hline Equatorial Guinea & 0 & 0.00 & 0 & 0.00 & 1200 & 0.05 & 0.00 \\
\hline
\end{tabular}

*Source: ICC, 2015

World coffee consumption is growing steadily at around 2.5 per year, and the demand for coffee is on the rise. Growth is fastest in the emerging markets, such as those in Eastern Europe and Asia, and in the coffee producing countries themselves. Moreover, the United States continues to be the biggest consuming country, making up 20 of the world consumption, followed by Brazil (17), Germany (8), and Japan (6) (Panhuysen and Pieerot, 2014). But in 2015, Finland topped the list of global coffee consuming countries followed by Sweden, the Netherlands and Germany (ICO, 2016). The demand is expected to reach 165 million bags in 2020 and calls for around 15 increase in green bean production over the next 5 years (ICC, 2015). Demand is very Strong in many countries, particularly in traditional markets (Canada, EU, Japan, Norway, Switzerland, USA, others) but the biggest potential is in emerging markets (Algeria, Australia, Russia, South Korea, Turkey, others) and coffee exporting countries (ICO, 2016).

Although global production and consumption have been rising for the past ten years, increases in production levels are not comparable to the increases in overall 
consumption. As the volume of coffee stocks decrease year by year, the pressure on global supply and demand is intense. Despite the fact that world production hit a tenyear low of 6.6 million tons in 2003/04, in 2010/11 it peaked at a record-high production level, reaching 8.2 million tons. The increased production levels were attributed to production increases in Brazil and Vietnam. At the same time, demand in producing countries such as Brazil and Vietnam expanded. As a result, world consumption levels reached a new peak of 8.1 million tons. While consumption has been increasing every year, coffee production naturally fluctuates on a biannual basis and therefore every second year production levels fall below demand. As a result, production shortages between 2003/04 and 2011/12 have accumulated to approximately 350,000 tons; the coffee stock at the end of the coffee season is half of what it was a decade ago (Promar Consulting, 2012).

Although Rwandan coffee is less than 1 of the world market and has no influence on futures prices, its producer price is linked to New York futures price. And although producer prices in Rwanda have not been recorded since 2006, neighboring Burundi, which also produces Arabica, has producer prices about the same as Rwanda's. Since the New York futures price has been increasing since 2006, it is generally assumed that producer prices in Rwanda have also been rising over the same period, as Burundi's have. In addition, it is anticipated that with the increase in producer prices in 2011, farmer' income also increased. In this way, coffee has brought significant wealth to producing countries and to their coffee farmers over the past few years, reconfirming its role as an important cash crop. Nevertheless, as long as the supply and demand situation does not improve, the threat of a price plunge like the one the world experienced in 2002 still hangs over the industry and speculation continues, the livelihood of coffee farmers remains at risk (Promar Consulting, 2012).

\section{The Situation of Coffee Sector in Rwanda}

Coffee in Rwanda can be dated back from its introduction by Germans in early in 1904, its first export in 1917. Upon its introduction, coffee became a major source of income and benefited from strong political support from the colonial authorities. It was imposed by the colonialists on agriculturists in 1927 and its cultivation was made obligatory in 1933. Legislation passed by the Government of Rwanda at Independence in 1963 prohibits the uprooting of coffee trees (Ngabitsinze et al., 2011). It was a policy initiative to obtain foreign currency during the colonial period, under which every farmer was each responsible for cultivating 70 coffee trees. Even now large-scale plantations do not exist; Rwanda's coffee production is carried out by small-scale farmers. 97 of Rwanda's coffee cultivation is Arabica. The Bourbon variety is cultivated instead of Caturra and Catuai, high-yield, pest-resistant varieties of Arabica coffee, because Caturra and Catuai are too difficult to cultivate in Rwanda. The Bourbon coffee has an excellent aroma and flavor, but every other year it becomes susceptible to pest infections. It is a variety that is rarely cultivated in other parts of the world, and Rwanda is one of the few countries still cultivating the Bourbon variety (Promar Consulting, 2012).

In the late 1980s, Rwanda experienced a decade-long quantitative and qualitative drop in production and exports due to an international market crisis. Moreover, due to falling income and hunger, farmers uprooted as many as 300,000 coffee trees and planted food crops (Boudreaux and Ahluwalia, 2009) and other attractive cash crops (Verwimp, 2003). The production of commercial green coffee has dropped from 40,000 tons (1985 - 1992) to $15,000-20,000$ tons (1996). The coffee export earnings amounted to only 20 million US\$ in 2001 against 60 million US\$ in 1990. The main coffee growing regions in Rwanda are located at 1,500-2,000 meters above sea level in the country's Western and Southern provinces. These regions are suitable for the cultivation of coffee, because of the rich soil with high volcanic ash content, ample annual rainfall of 2,000 mm, and abundant sunshine. In the Western province, the optimal Arabica cultivation areas stretch in a narrow band from north to south along Lake Kivu, particularly in Nyamasheke and Rusizi districts located at the southernmost part of Lake Kivu. In the Southern province, coffee cultivation is concentrated in Hue district. In addition, large amounts of Arabica is also grown across areas stretching from Muhanga District in Southern Province to Gakenke in Northern Province (Promar Consulting, 2012).

According to the National Coffee Census, there are approximately 72 million coffee trees planted in Rwanda, on a total of approximately 2,900 hectares of cultivated land. There are roughly 500,000 coffee growers and each grows an average of 183 trees in an average cultivation area of 0.07 hectares (Table 3 ). The average cultivation area per grower is less than one-tenth of its neighbor Tanzania. This illustrates once again how Rwanda's coffee production is characterized by small-scale farming. The average number of trees these farmers have is around 200, covering 0.1 hectares (Technoserve, 2012). The total area grown by farmers affiliated with cooperatives is estimated to be 13,500 hectares, where each cooperative works with farmers cultivating 75 hectares in total (MINAGRI, 2012). Total area in coffee is currently 35,000 hectares grown at altitudes between $900-1900 \mathrm{~m}$. 97 of coffee is Arabica, mainly 'bourbon' type and the total Production between 267,000 and 420,000 bags per year with 400,000 small holder farm families produce it and depend on it for their livelihoods. The total area in coffee is currently 42,000 hectares grown and it is grown in most provinces in the country at an altitude less than $1900 \mathrm{~m}$ (NAEB, 2017).

\section{The Value Chain in Coffee Sector of Rwanda}

The transformation of Rwanda's coffee sector has happened relatively quickly. In 2000, Rwandan farmers were producing semi-processed coffee for sale on world markets. Farm gate prices paid to farmers were low (60 Rwandan francs per kilogram) and the prospects for 
farmers and exporters to increase income or profits were limited. Since the late 1990s the government has liberalized the sector, removing a variety of barriers to trade, creating new incentives for groups and individuals to invest in coffee production and facilitating entrepreneurship in the coffee industry. In a focused, decade-long effort the government, working with the private sector and with donors, has reshaped this important industry: the regulatory framework for coffee production has been modified, over 100 coffee washing stations have been built, donors have supported the development of market linkages between producers and foreign buyers, cooperatives have formed, and smallholder farmers are working together in an effort to increase quality and improve marketing and branding. These changes have important effects on the ground in Rwanda. Coffee continues to generate important export revenue for the country. While figures vary year-to-year, in 2008 coffee exports generated just over \$47 million in revenue, compared with \$35 million in 2007 (EDPRS, 2012).

The distribution system of coffee in Rwanda was completely privatized in 1995. Cooperatives, private CPU facilities and exporters are currently responsible for processing and distribution. Before 1995, all processing facilities, as well as the majority of the capital of the two domestic exporters were owned by the government. Moreover, a price stabilization fund had been established, and prices such as the producer price and exporters profit margins were entirely determined by the government, regardless of the international price. While the system guaranteed farmers a certain level of profit despite fluctuations of international prices, no additional payments were made to farmers when international prices increased, nor was there a price difference according to quality differences (Promar Consulting, 2012).

Changes in the coffee sector began shortly after the genocide, when the government opened the market for coffee export to increased competition. The method for pricing beans also changed. Rather than dictate a single price for the entire season OCIR-Café (now known as the Rwanda Coffee Development Authority), sets a minimum weekly reference price, in consultation with stakeholders, a basis from which a sales price per kilo may be negotiated (Boudreaux, 2011).

Additionally, because of the government's inefficient administration of the system, tax increases were seen in some case. In 2005 the distribution system was liberalized and all state-owned processing facilities and export companies were sold to the private sector. Through privatization, new stakeholders (private processors and exporters) found their way into the industry. Presently, there are more than $200 \mathrm{CPU}$ facilities in Rwanda, of which 60 are owned by cooperatives and the remaining 40 are owned by private companies. The three major exporting companies, Coffee Business Center (CBC), RWACOF, and Rwanda Trading Company together take up 80 of the export market. Moreover, cooperatives such as COOPAC and RWASHOSCCO are exporting on their own. The government's current direct role in coffee distribution is limited to quality inspections and issuance of export permits. The government also holds conferences with cooperatives and exporters in order to decide the minimum cost to pay farmers for their product (taking into account factors such as New York futures price and production cost). The establishment of a Rwandan Commodity Exchange is scheduled for the next one to two years and research is currently being conducted on possible implementation models (Promar Consulting, 2012).

Distribution channels for coffee differ whether the beans have been processed through hand-pulping or CPU processing. Since 80 of the output in Rwanda is still processed through hand-pulping, the hand-pulping channel is the major distribution channel. In hand-pulping wet processing, each farmer picks the cherries, processes them into parchment beans, and then sells them to cooperatives and agents. Then, the beans are processed into green beans in secondary processing facilities owned by cooperatives and exporters. The end product is exported. For CPU processing, farmers sell cherries to CPU facilities owned by cooperatives and privates companies. The cherries are then transformed into parchment beans and green beans, and then exported (Figure 1).

Table 3 Coffee farm size per household*

\begin{tabular}{c|cc}
\hline $\begin{array}{c}\text { Coffee farm size } \\
\text { per household }\end{array}$ & $\begin{array}{c}\text { Number of } \\
\text { coffee trees }\end{array}$ & $\begin{array}{c}\% \\
\text { of farmers }\end{array}$ \\
\hline$<0.04$ ha & $<100$ & 53.30 \\
$0.04-0.12$ ha & $100-299$ & 34.20 \\
$0.12-0.24$ ha & $300-599$ & 8.08 \\
$0.24-0.49$ ha & $600-1199$ & 3.30 \\
$0.5-1$ ha & $1200-2499$ & 0.75 \\
$1-4$ ha & $2500-10000$ & 0.20 \\
$>4$ ha & $>10000$ & 0.02 \\
\hline
\end{tabular}

*Source: Technoserve, 2012

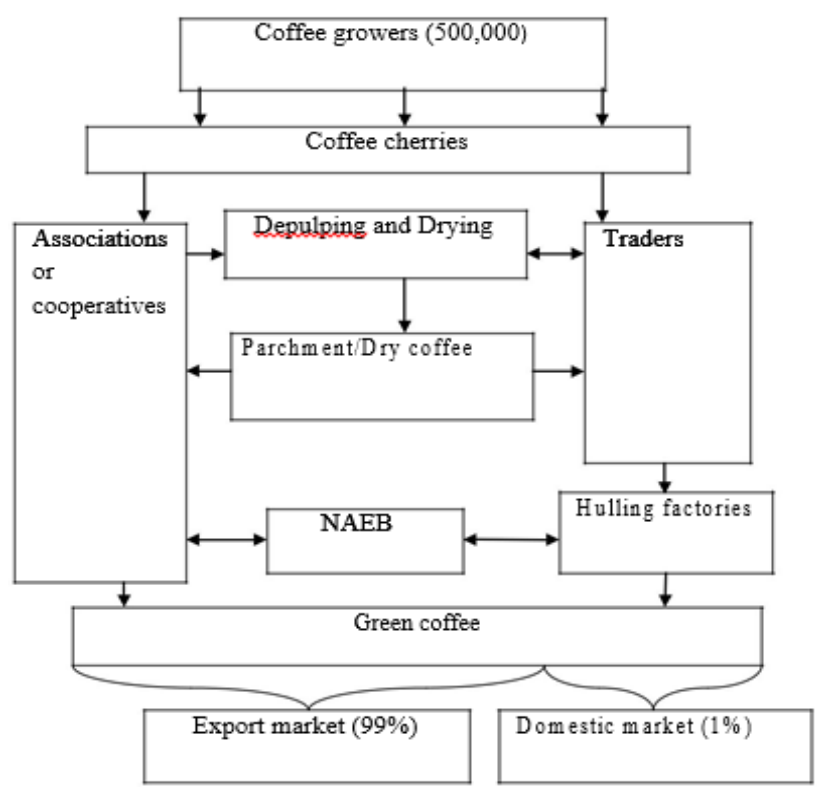

Figure 1 Coffee supply chain in Rwanda (Source: Promar Consulting, 2012) 


\section{Rwandan coffee local consumption and major destinations}

Over the past five years, Rwanda has made spectacular strides in developing a quality coffee industry. Prior to 2001, Rwanda, a traditional producer of mediocre quality semi-washed Arabica coffee, was unknown to importers, roasters, and consumers of specialty and premium grade coffees. Today, Rwandan coffee is a sought after origin. The country's fully-washed Arabica are being sold through more than 30 renowned specialty roasters and importers in the United States, Europe and Japan. Data on coffee exports by destination over a period of 4 years (2005-2008) was used. Results of the study indicated that Rwandan coffee has predominantly been marketed to European destinations that include Sweden, Switzerland, Germany, France, UK and Russia and in general these markets increased by 287 over the last 4 years. However, coffee trade in Rwanda accounts for a small proportion (0.69) in global export coffee market (Mutandwa et al., 2009).

In 100 of total coffee produced in Rwanda, 84 of Rwanda coffee export went to the four major clients, Switzerland alone bought 60.10 of Rwanda coffee, China 10.69, United States Of America 7.64 and Belgium 5.89. The diagram below shows volume percentage of tea purchased by each buyer country (Figure 2).

The Demand far outstrips supply, and importers regularly purchase coffee at prices two to three times the international reference price months before the cherries have been harvested and processed. Rwandan fully washed coffees now regularly place among the top entrants in African tasting competitions, frequently scoring higher marks than coffees from established world class origins such as Kenya and Ethiopia. The explosion of Rwanda on the quality coffee market has been covered by international and national media such as CNN, the New York Times, Time Magazine and the Washington Times among others (USAID, 2006).

Although Rwandan coffee is less than 1 of the world market and has no influence on futures prices, its producer price is linked to New York futures price. And although producer prices in Rwanda have not been recorded since 2006, neighboring Burundi, which also produces Arabica, has producer prices about the same as Rwanda's. Since the New York futures price has been increasing since 2006, it is generally assumed that producer prices in Rwanda have also been rising over the same period, as Burundi's have. In addition, it is anticipated that with the increase in producer prices in 2011, farmer' income also increased. In this way, coffee has brought significant wealth to producing countries and to their coffee farmers over the past few years, reconfirming its role as an important cash crop. Nevertheless, as long as the supply and demand situation does not improve, the threat of a price plunge like the one the world experienced in 2002 still hangs over the industry and speculation continues, the livelihood of coffee farmers remains at risk (Promar Consulting, 2012).

\section{Rwanda's National Coffee Strategy}

In 2002 the government issued a National Coffee Strategy that outlined a plan for capturing a larger share of the specialty coffee sector (Table 4). A production target of 44,000 tons of coffee was set for 2010, 63 percent of which would be fully washed. These production targets have, however, never been met (Worldbank, 2011)

The shift away from low-quality coffee to high-quality specialty coffee was designed to break a perceived "low quality, low-quantity trap." As noted, Rwandan farmers were producing low-quality coffee that sold for a low price. Low sales prices meant that farmers lacked revenue to invest in improvements. Without sufficient income, farmers could not invest in capital to improve the quality of their beans-hence, the trap (Boudreaux, 2011).

Table 4 Increase of productivity from $600 \mathrm{~kg}$ to $1000 \mathrm{~kg} *$

\begin{tabular}{c|ccc}
$\begin{array}{c}\text { Coffee farm } \\
\text { size per } \\
\text { household (ha) }\end{array}$ & $\begin{array}{c}\text { Farm } \\
\text { size }\end{array}$ & $\begin{array}{c}\text { Productivity } \\
600 \mathrm{~kg} \\
\text { green } \\
\text { coffee/ha }\end{array}$ & $\begin{array}{c}\text { Value at } \\
\text { targeted } \\
1000 \mathrm{~kg} / \mathrm{ha}\end{array}$ \\
\hline $\begin{array}{c}<0.04 \text { ha } \\
0.04-0.12 \text { ha }\end{array}$ & 53.30 & $<24$ & $<40$ \\
$0.12-0.24$ ha & 8.08 & $24-72$ & $40-120$ \\
$0.24-0.49$ ha & 3.30 & $144-288$ & $120-240$ \\
$0.5-1$ ha & 0.75 & $288-600$ & $500-1000$ \\
$1-4$ ha & 0.20 & $600-2400$ & $1000-4000$ \\
$>4$ ha & 0.02 & $>2400$ & $>4000$ \\
\hline
\end{tabular}

*Source: Worldbank, 2011

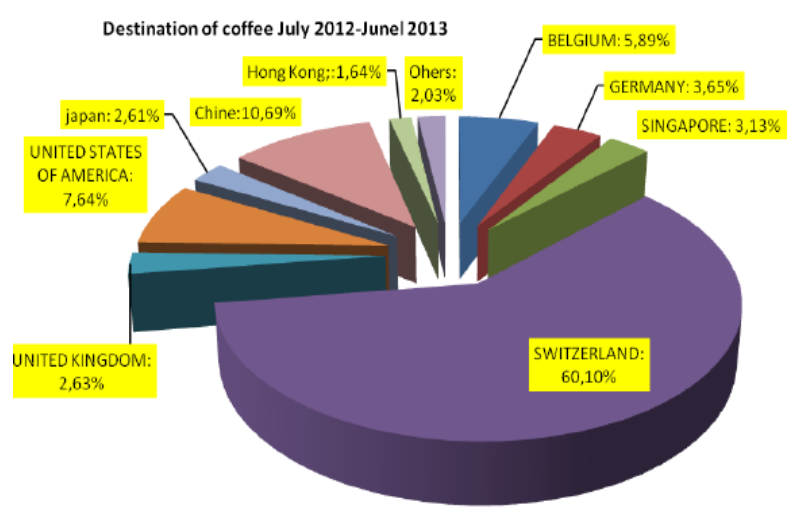

Figure 2 Destination of Rwanda coffee 2012 (Source: NAEB, 2012)

The National Coffee Strategy was designed to break this trap and increase income and revenue and improve price stability, as specialty coffee prices fluctuate less dramatically than does the price for semi-washed coffee. In an attempt to meet these targets, coffee-sector stakeholders focused on strengthening and supporting producer cooperatives, identifying sites for and supporting the building of coffee washing stations, replanting aging tree stock, improving quality control throughout the industry and strengthening the Rwanda brand. The coffee sector remains a high priority industry 
for 15 the government, one of four focal sectors identified in its recent Economic Development and Poverty Reduction Strategy (Boudreaux, 2011).

The Rwandan government, through Vision 2020, has set a target of a yearly average economic growth rate of 4.6 , and a target of increasing exports by 15 . The coffee industry is considered a priority industry because it brings in foreign currency income. In total six industries have been established as priority industries and the coffee industry is considered the third priority following the tourism and tea industries. Compared to other industries, the coffee industry has the technical capacity to compete and the potential for product differentiation. These strengths reflects the fact that the Rwandan government has used foreign aid to enhance local wet processing facilities, specialty coffee sales, and marketing initiatives. The intention is to use these strengths advance further downstream along the value chain to high-end markets abroad, capturing more of the profits along the chain. However there are still many production and institutional concerns that have not yet been addressed through aid (Promar Consulting, 2020).

\section{Contribution of coffee to GDP and Rural Income in Rwanda \\ In Rwanda, Coffee plays a major role in the economy} of the country, contributing significantly to foreign exchange earnings and to the monetization of the rural economy. For many years coffee used to be Rwanda's top export product and thus main source of foreign exchange income (Tobias and Boudreaux, 2009). It provides a livelihood for almost 500,000 Rwandan families (corresponding to approximately 2 million people and 25 per cent of the total population) who belong to cooperatives and grow coffee in small plots (Boudreaux, 2007).

The Coffee sub-sector is coordinated under the National Agricultural Export Development Board (NAEB) whose responsibilities are: Support to the coffee production by providing technical assistance and planting material to farmers, Support to the coffee processing promotion, marketing and export of Rwanda coffee, participation in the development of the policy and strategies governing the sector and ensure the implementation of policies as they affect production, processing, marketing research and training in the sector. In 2012, coffee accounted for almost 30 of Rwanda's total export revenue. Considering national targets to increase export revenues by 18 , a few simple measures to improve the performance of the sector could have substantial effects on the country's economic growth (Macchiavello and Morjaria, 2015).

Rwanda, like some other countries in East Africa, produces some of the best coffee in the world. This creates the opportunity for Rwanda to increase its exports through value addition. Yet, since 2006, the Rwandan coffee sector has seen a gradual decline in export volumes though this was offset by a strong world price of coffee. Between 2006 and 2012, coffee export volumes fell from $26 \mathrm{~m} \mathrm{~kg}$ to $20 \mathrm{~m} \mathrm{~kg}$. In contrast, the world price of coffee has climbed from $\$ 2.50 / \mathrm{kg}$ in 2006 to a peak of $\$ 6.06 / \mathrm{kg}$ in 2012, offsetting the effects of the fall in production (Macchiavello and Morjaria, 2015).
The increased value of Rwandan coffee export share

One way to more sustainably increase revenues from coffee is to increase the percentage that is fully washed (which has grown dramatically since 2002 but is currently just 30-40 exports) (Figure 3). Macchiavello and Morjaria, 2015 found that, on average, the price of fully washed coffee is around $\$ 4.45 / \mathrm{kg}$, whereas ordinary coffee earns just $\$ 3.05 / \mathrm{kg}$. This means that for each $\mathrm{kg}$ of coffee that is processed in a coffee washing station rather than in a farmer's house, Rwanda earns an additional $\$ 1.40$ in export revenues. Consequently, if Rwanda were to double the amount of coffee exported as fully washed coffee, holding constant total coffee export volumes and world coffee prices, it could expect a 10-20 increase in coffee export revenues. This would amount to an additional 3-6 increase in total export revenues.

Despite the high grade of Rwandan coffee, the effective coffee export price (calculated by dividing the export value by the weight), has fallen consistently below the world price of coffee (the green bars in Figure 3). Between 2006 and 2012, both the Rwandan and the world price of coffee grew sharply. Since 2012, there has been a gradual price reduction for both. The IGC study found some evidence that the gap between the Rwandan and world price of coffee has narrowed since 2011. One interpretation is that Rwandan's are managing to upgrade to higher value coffee. Indeed, both the percentage of coffee that is fully washed has risen from 0 in 2002 to 40 in 2014 (Figure 3).

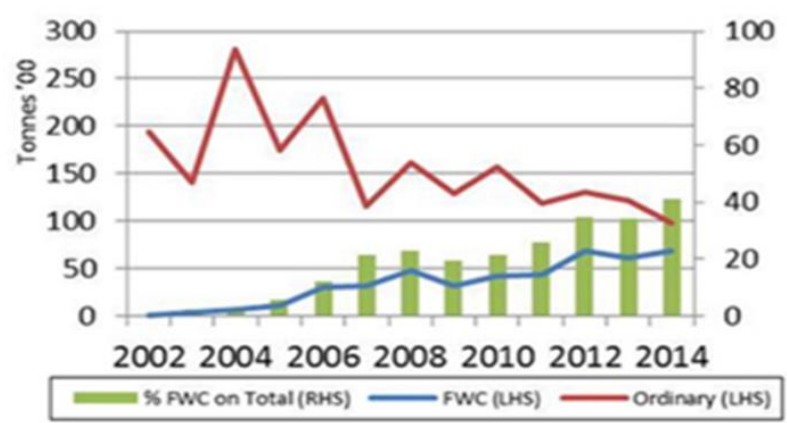

Figure 3 Production of Fully Washed Coffee vs. Ordinary Coffee (Source: Macchiavello and Morjaria, 2015)

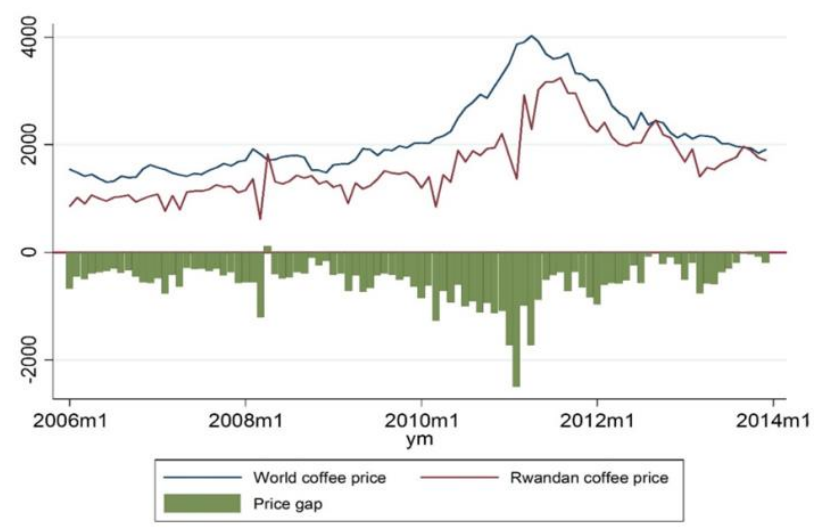

Figure 4 World Price of Coffee (rwf/kg) (Source: Spray, 2015) 
Rwandan coffe production trend overtime

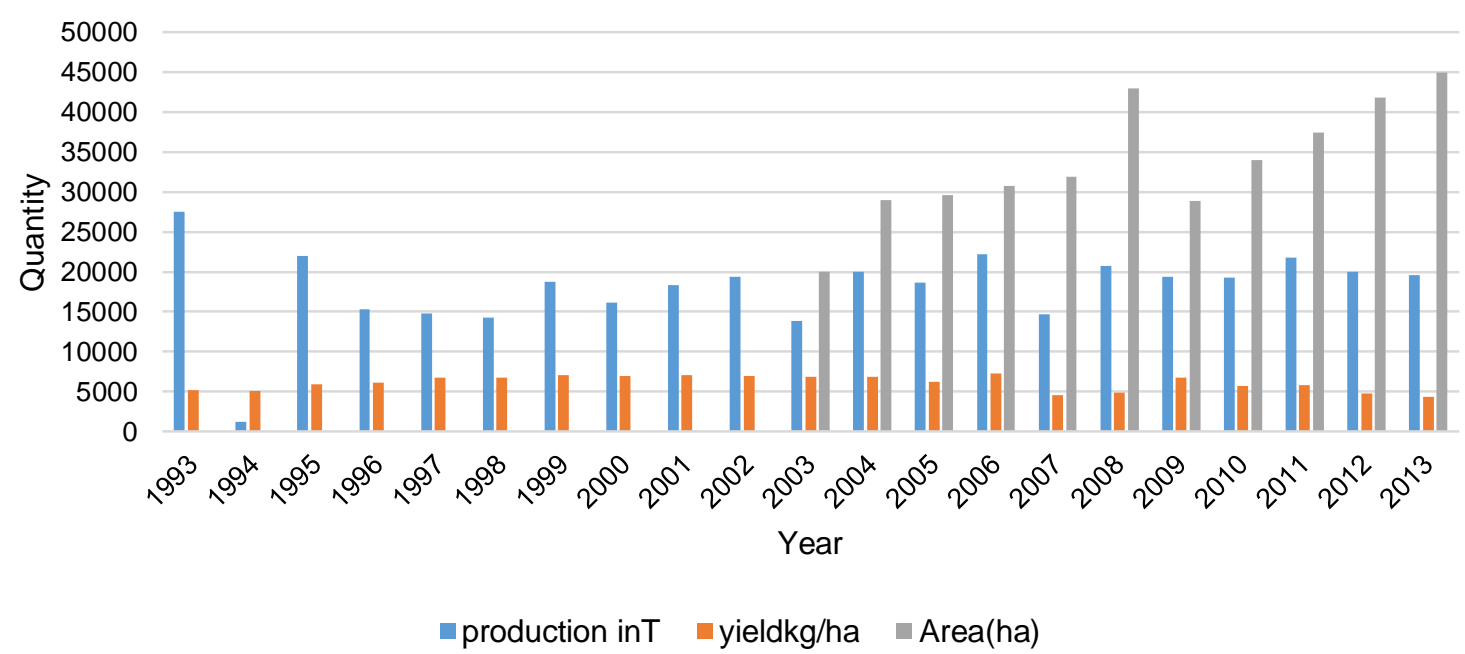

Figure 5 Rwandan coffee production over time and reported climate influence (1993 - 2013) (Source: MINAGRI, 2013)

However, fully washing coffee is only half of the story in creating quality coffee. FWC guarantees consistent coffee without defects, which can thus be branded, preordered, and sold with a premium. In order to guarantee quality coffee, the government has begun to put in place infrastructure and training. If this is achieved the export price will go up, community incomes increase, and the possibility of direct trade and private financing will be unlocked. This has been demonstrated with success in countries such as Ethiopia and Costa Rica (NAEB, 2014).

As a small producer Rwanda's coffee export price cannot influence the world price of coffee (Figure 4). Price fluctuations are a fact of life. However, to reduce the vulnerability of the Rwandan coffee sector to price shocks there are a number of possible mitigation strategies. One way to reduce the susceptibility of Rwandan producers to world price fluctuations is to increase the percentage of Rwandan coffee sold as high quality specialty coffee. This is because niche coffee is bought by higher income consumers who are less responsive to changes in prices. By contrast, low value coffee is often sold in commodity markets with high price variability. Rwanda is fortunate to produce some of the best coffee in the world so upgrading quality has an enormous payback that can better weather demand shocks, should they occur (Spray, 2015).

Rwanda might consider encouraging the expansion of the East African Commodity Exchange to include commodity level coffee. A commodity exchange can help mitigate the risk of compressed sales prices by attracting a more diverse market of buyers to the region, to encourage stronger price competition for regional exports. While this does not fully insure against supply and demand shocks, it at least brings better, more stable, prices to farmers through access to a larger pool of potential buyers and the potential to access sales prices averaged across the harvest season. However, when selling to the commodity exchange is compulsory it can damage coffee quality (Spray, 2015).

\section{Climate Influence on Coffee Sector in Rwanda}

In Rwanda, little is known with regard to the impact of climate on coffee production. However, a low yield was reported in 2007 and climate variability was quoted among the causes (MINAGRI 2008). Insufficient rainfall in the last three months of 2006 (the period of coffee flowering) proceeding the short dry season in the first two months of 2007 was recorded. The reduced rainfall was also poorly distributed across coffee growing regions in Rwanda. However, in 2008 the situation improved since the production of 2008 was increased by about 40 due to sufficient rainfall in the period of September/November 2007 and in March 2008 ( MINAGRI 2008). Figure 5 shows the evolution of coffee production from 1993 to 2013.

Coffee exports recorded a poor performance decreasing by $31.3 \%$ in value and $13.2 \%$ in volume due to bad weather especially lack of rainfall in the fourth quarter of 2013. The decline in value is explained both low production as a result of unfavourable weather condition and the fall in the international commodity prices. In addition, the level of stocks end 2013 was low (2,560 tons) compared to the stock of end $2012(3,262$ tons). Coffee exports remained dominated by ordinary coffee which represent $50 \%$ of total production and dropped by $23.3 \%$ to 8,912 tons in $2013 / 2014$ from 11,615 tons in 2012/2013. Fully washed coffee also decreased by $13.7 \%$ from 7,169 tons to 6,186 tons in 2013/2014 (MINAGRI, 2013 ).

\section{Conclusion and Recommendations}

The research has identified the economic and the livelihood indicators for farmers who are engaged in coffee production and also gives the Rwandan coffee sector' situation and its position in the global coffee market. The agriculture sector generally is pressured by climate change in the way that periodic floods and droughts (extreme events) already cause major socioeconomic impacts and reduce economic growth in 
the country. The country is characterized by dramatic contrasts in temperature and rainfall as the elevation changes from the lowland savannah areas of the east to the mountain chains of the west. According to the above provided indicators, there is no doubt that Coffee Sector has made a great improvement to the global economy, to the GDP of Rwanda and to the rural Rwandan Socioeconomic status. In Rwanda, coffee industry has undergone a remarkably successful transformation by positioning its coffee as an appreciated and recognized brand in the international premium coffee market, which has created a high value for Rwanda's economy. Many farmers still need to be convinced that it is possible to ensure high yields in a profitable manner while enforcing sustainable practices. Although several initiatives have demonstrated the potential gains, it will take time to transform the whole coffee industry to comply with international sustainability standards. With the limited capacity of extension services providers, the coffee farmer organizations (cooperatives or unions) are the strongest pillar of the sustainable coffee sector in Rwanda.

The study concluded that adding value to the coffee supply chain of Rwanda is adding direct economic benefits and important indirect social benefits to the lives of individuals and to the health of communities in Rwanda. Moreover, more effort should continue to raise the profile of the Rwandan coffee sector to meet sustainability standards and the proper use of chemical fertilizers, solid marketing channels and climate change adaptations measures would be the fair ways of making the sector more profitable. Also, considering national targets to increase coffee export revenues, a few simple measures to improve the performance of the sector could have substantial effects on the country's economic growth. In the same way, sustainability coffee sector should not only focus on the quantity but also on the quality coffee production. And finally, to find a way of attracting more investors in coffee processing and create new export destinations.

\section{References}

AfDB. 2010. The African Development Bank Group Chief Economist Complex. Coffee Production in Africa and the Global Market Situation Commodity Market Brief, 1(2): 12 July, 2010.

Bizimana C, Usengumukiza F, Kalisa J, Rwirahira J. 2012. Trends in Key Agricultural and Rural Development Indicators in Rwanda, July 2012, Minagri, Rwanda

Boudreaux K. 2007. State Power, Entrepreneurship, and Coffee: The Rwandan Experience, Mercatus Policy Series, October 2007, George Mason University,

Boudreaux KC. 2011. Economic Liberalization in Rwanda's Coffee Sector:A Better Brew for Success. Yes Africa Can: Success Stories From A Dynamic Continent, Editors: Punam ChuhanPole And Manka Angwafo, World Bank.

Boudreaux KC, Ahluwalia P. 2009. Cautiously Optimistic: Economic Liberalization and Reconciliation in Rwanda's Coffee Sector Denver Journal of International Law and Policy, 37(2): 147-200.

ED\&F MAN. 2013. Insight special: 230 years of ED\&F MAN, Coffee Division. Available online at: http://www.volcafespecialty.com /wp-content/uploads/2013/01/ April-2013-230-years-of-EDF-Man.pdf
EDPRS. 2012. Coffee Output May Climb 13 Percent in 2010, The New Times, January 8, 2010. 42 Ibid. (coffee output may climb) EDPRS, p. 11.

GoR. 2011. Government of Rwanda National Export Strategy (NES). GoR, Minecofin, Kigali

GoR. 2013. Government of Rwanda, Poverty Reduction Strategy Paper, December 2013 IMF Country Report No. 13/360

ICC. 2015. Sustainability of the Coffee Sector in Africa, International Coffee Council, International Coffee Organization, $114^{\text {th }}$ Session, 2-6 March 2015, London, United Kingdom

ICO. 2016. The Current State of the Global Coffee Trade. Available at: http://www.ico.org/monthly_coffee_trade_stats.asp.

Macchiavello R, Morjaria A. 2015. Coffee Washing Stations in Rwanda, IGC Policy Memo. Available at: https://www.theigc.org/wp-content/uploads/2015/02/ Macciavello-and-Morjaria-2015-Project-Memo.pdf

MINAGRI. 2008. National Annual Agricultural Production. Ministry of Agriculture and Animal Resources, Government of the Republic of Rwanda, Kigali, Rwanda.

MINAGRI. 2013. Resultats de l'Enquete National Agricole 1984, Rapport 1, Vol. 2. March 1986.

MINAGRI. 2013. National Coffee Strategy Rwanda 2009-2012, Ministry of Agriculture \& Animal Husbandry together with Ministry of Trade \& Industry, (December, 2008), p. 8-9, Available at: http://amis.minagri.gov.rw/content/rwandanational-coffee-strategies-2009-2012. Here after NCSR 20092012

MINAGRI. 2012. Agriculture, forestry and fisheries of Rwanda, Fact-finding Survey for the Support of Aid to Developing Countries (Fiscal Year 2011 Research Project) Supported by the Ministry of Agriculture, Forestry and Fisheries, March 30, 2012.

Mutandwa E, Kanuma NT, Rusatira E, Kwiringirimana T, Mugenzi P, Govere I, Foti R. 2009. Analysis of coffee export marketing in Rwanda: Application of the Boston consulting group matrix. Department of Rural Development and Agribusiness, Faculty of Agriculture, Higher Institute of Agriculture and Animal Husbandry (ISAE-Busogo), Musanze, Rwanda.

NAEB. 2012. National Agricultural Export Development Board, Statistics Report 2012 of Coffee, Tea and Horticulture. Available at: http://www.naeb.gov.rw/fileadmin/StatisticAnnual/NAEB_STATISTICS_EPORT_2012.pdf

NAEB. 2014. Current status of the coffee sector in Rwanda and way forward to increase farmers' household income through increased coffee revenues, $11^{\text {th }}$ AFCA Conference, Bujumbura, Burundi, $13^{\text {th }}-15^{\text {th }}$ Feb. 2014.

NAEB. 2017. National Agricultural Export Development Board, Available at: http://www.naeb.gov.rw/index.php?id=48\&L=2\% 27A\%3D0\&type $=$ atom $\% 2 \mathrm{FRK} \% 3 \mathrm{D} 0 \% 252$

Ngabitsinze JC, Mukashema A, Ikirezi M, Niyitanga F. 2011. Planning and costing adaptation of perennial crop systems to climate change: Coffee and banana in Rwanda Case study report. Available at: https://www.academia.edu/26700747/ Planning_and_costing_adaptation_of_perennial_crop_systems _to_climate_change_Coffee_and_banana_in_ Rwanda_Case_ study_report.

NISR. 2014. Fourth Population and Housing Census, Rwanda 2012, Population Projections Thematic Report, National Institute of Statistics of Rwanda, pp. 155.

Panhuysen S, Pierrot J. 2014. Coffe Barometer, hivos IUCN Nederland, OXFAM Novib solidaridad WWF. Available at: https://hivos.org/sites/default/files/coffee_barometer _2014_report_1.pdf

Promar Consulting. 2012. Agriculture, Forestry And Fisheries of Rwanda, Fact-finding Survey for the Support of Aid to Developing Countries (Fiscal Year 2011 Research Project) Supported by the Ministry of Agriculture, Forestry and Fisheries. Available at: http://www.promarconsulting.com/site/ wp-ontent/uploads/2012/05/Rwanda_2012.pdf 
Spray J. 2015. International Growth Center. How coffee can drive economic growth. Available online at: http://www.theigc.org/blog/how-coffee-can-drive-economicgrowth/

Technoserve. 2012. Impact Evaluation of TechnoServe's Rwanda Coffee Agronomy Program \& the "Monitoring Effect", Presentation to 2012 IPAR Annual Research Conference.

The New Times. 2009 . Twenty-One Coffee Cuppers Trained on Quality, August 29, 2009, pointing out that while Rwanda now has 100 coffee cuppers, less than half are trained and licensed to international standards.

Tobias J, Boudreaux K. 2009. The Role of Entrepreneurship in Conflict Reduction in the Post Genocide Rwandan Coffee Industry: Quantitative Evidence from a Field Study, Mercatus Center Working Paper, No. 09/24 June, 2009.

USAID 2006. Assessing Usaid's Investments in Rwanda's Coffee Sector Best Practices and Lessons Learned To Consolidate Results and Expand Impact. Available at: http://pdf.usaid.gov/pdf_docs/Pnadg793.pdf
USAID. 2007. Country Report on Rwanda, the Economist Intelligence Unit notes: 'Stagnation in many of the traditional coffee-drinking markets of North America and Western Europe will restrict growth in demand, although demand for highquality specialty coffees, including Rwanda's finest fully washed Arabica, will remain more buoyant.' "Country Report: Rwanda," Economist Intelligence Unit, (February 2007), p. 10. 4 “Assessing USAID's Investments," p. 4.

Verwimp P. 2003. The Political Economy of Coffee, European Journal of Political Economy, 19(2): 161-181.

WHO. 2015. Succes Factors for Women's and Children's Health Rwanda, Ministry of Health Rwanda, Switzerland.

Woldbank. 2011. Yes Africa Can Success Stories form a Dynamic Continent, Editors: Pole, P.C., Angwafo, M. 